\title{
RADIOCARBON ANALYSIS OF TREE RINGS FROM A 15.5-CAL KYR BP PYROCLASTICALLY BURIED FOREST: A PILOT STUDY
}

\author{
Kazuho Horiuchi $^{1} \bullet$ Shinya Sonoda ${ }^{1} \bullet$ Hiroyuki Matsuzaki $^{2} \bullet$ Motonari Ohyama $^{3}$
}

\begin{abstract}
We have determined the radiocarbon ages for 40 -yr-interval tree rings in 2 fossil trees of the Towada Hachinohe buried forest, northeastern Honshu Island, Japan. The ${ }^{14} \mathrm{C}$ ages range from 13.0 to $13.3 \mathrm{kyr} \mathrm{BP}$ (about $15.5 \mathrm{cal} \mathrm{kyr} \mathrm{BP}$ ). The weighted average of the ${ }^{14} \mathrm{C}$ age of the outermost 5 rings is $13,133 \pm 33 \mathrm{BP}$, which can be calibrated to $15,363-15,679$ cal BP by using the IntCal04 standard curve (Reimer et al. 2004). The estimated $\Delta^{14} \mathrm{C}$ values range between 265 and $300 \%$ and show approximately sinusoidal fluctuation of an indicated 200 -yr cycle, perhaps reflecting contemporary solar activity change. Comparison between the tree ${ }^{14} \mathrm{C}$ profile and the Cariaco Basin ${ }^{14} \mathrm{C}$ record provides further information on the accurate date of the Towada Hachinohe buried forest and the eruption that produced it. ${ }^{14} \mathrm{C}$ analysis of tree rings from the buried forest may contribute to the construction of a better ${ }^{14} \mathrm{C}$ calibration curve and the elucidation of solar activity change during the last glacial period, as well as possible global and regional impacts of the huge eruption from Towada Volcano.
\end{abstract}

\section{INTRODUCTION}

Accurate and precise knowledge of past radiocarbon concentration in the atmosphere is crucial not only for ${ }^{14} \mathrm{C}$ dating but also for solar and Earth system science. Long-term records of atmospheric ${ }^{14} \mathrm{C}$ concentration have been reconstructed by using evidence derived from tree rings (e.g. Stuiver et al. 1986), coral (e.g. Bard et al. 1998), speleothems (e.g. Beck et al. 2001), terrestrial fossils in varved sediments (e.g. Kitagawa and van der Plicht 2000), and biotic or abiotic carbonates in marine and lacustrine sediments (e.g. Voelker et al. 2000; Hughen et al. 2004a,b; van der Borg et al. 2004). These records have been used, for example, to determine past changes in solar activity (e.g. Stuiver and Quay 1980; Solanki et al. 2004) and for evaluating ocean circulation changes (e.g. Broecker et al. 2004; Robinson et al. 2005).

Tree growth rings are evidently the best archives of past ${ }^{14} \mathrm{C}$ concentration. Unlike the other archives, tree rings directly record information on atmospheric ${ }^{14} \mathrm{C}$, and we do not need to consider any reservoir ages. The single-year resolution that is possible from the rings is superior to the time resolution derived from other records (e.g. Stuiver and Braziunas 1998; Miyahara et al. 2006). Nevertheless, tree-ring ${ }^{14} \mathrm{C}$ age determinations have been until now restricted in their applicability to within the last $12.4 \mathrm{cal} \mathrm{kyr} \mathrm{BP}$ (Reimer et al. 2004), except for a few scattered results (e.g. Gandou et al. 2004; Kromer et al. 2004). The reasons are the questionable precision of the ${ }^{14} \mathrm{C}$ measurement, the scarcity of samples, and the weak framework of calendar age for the last glacial phase. However, the precision of accelerator mass spectrometry (AMS) ${ }^{14} \mathrm{C}$ measurements is now progressively increasing (e.g. Fifield 2000; Bronk Ramsey et al. 2004). Tree-ring samples from the last glacial age are often excavated from middle- to low-latitude volcanic islands such as those of Japan. With the help of local dendrochronology, the ${ }^{14} \mathrm{C}$ wiggle-matching technique applied to tree rings of the last glacial period (Kromer et al. 2004) and certain varved sediments (Kitagawa and van der Plicht 1998; Hughen et al. 2000, 2004b) may solve the problem of calendar age. Studies on former ${ }^{14} \mathrm{C}$ atmospheric concentration based on tree rings of the last glacial epoch are thus now becoming feasible.

We have been exploring the possibility of high-resolution AMS ${ }^{14} \mathrm{C}$ analysis of tree rings by using 2 stumps of coniferous trees obtained from a 15.5-cal kyr BP forest buried beneath volcanic ash. The

\footnotetext{
'Department of Earth and Environmental Sciences, Faculty of Science and Technology, Hirosaki University, Bunkyo-chou, Hirosaki, Aomori, 036-8561 Japan. Corresponding author. Email: kh@cc.hirosaki-u.ac.jp.

${ }^{2}$ MALT, Faculty of Technology, The University of Tokyo, Yayoi 2-11-16, Bunkyo-ku, Tokyo, 113-0032 Japan.

${ }^{3}$ Botanical Garden, Tohoku University, Kawauchi, Aoba-ku, Sendai, 980-0862 Japan.
} 
forest is composed mainly of fossil standing trees preserved in time by a sequence of pyroclastic fall and/or flow deposits. Based on this unique situation, it is possible to cross-check the validity of ${ }^{14} \mathrm{C}$ measurements using multiple trees probably having the same death age. In this paper, we describe the localities and occurrence of the 2 stumps and the preliminary results of their ${ }^{14} \mathrm{C}$ analysis. We also discuss the excellent agreement of the stump ${ }^{14} \mathrm{C}$ profiles, in which we find a fluctuation of a few percent in $\Delta^{14} \mathrm{C}$, which is perhaps related to past solar activity. The tree ${ }^{14} \mathrm{C}$ profiles are compared with the Cariaco Basin ${ }^{14} \mathrm{C}$ record (Hughen et al. 2004b) to provide a context for ${ }^{14} \mathrm{C}$ records of this period and the possible impact of the eruption of the volcanics.

\section{MATERIALS}

Figure 1 shows the localities and occurrence of the material we analyzed (stumps A and B). The 2 erect stumps were collected from the Towada Hachinohe buried forest in 2003. This forest is located in the northeastern part of Honshu Island, Japan, and has been thoroughly investigated from paleobotanical and geological viewpoints (e.g. Oike and Nakagawa 1979; Hayakawa 1985; Terada et al. 1994; Noshiro et al. 1997). The forest is buried by a meters-thick pyroclastic fall deposit (ToHP), which is overlain by $>10 \mathrm{~m}$ of pyroclastic flows $(\mathrm{ToH})$. Volcanological and sedimentological investigations show that the eruption of volcanics was geologically simultaneous and occurred at the same Towada Volcano (Oike and Nakagawa 1979; Hayakawa 1985; Machida and Arai 2003). Although the sampled specimens are $4.5 \mathrm{~km}$ apart, we can easily recognize the uniformity of the buried forest within its geological setting (Figure 1).

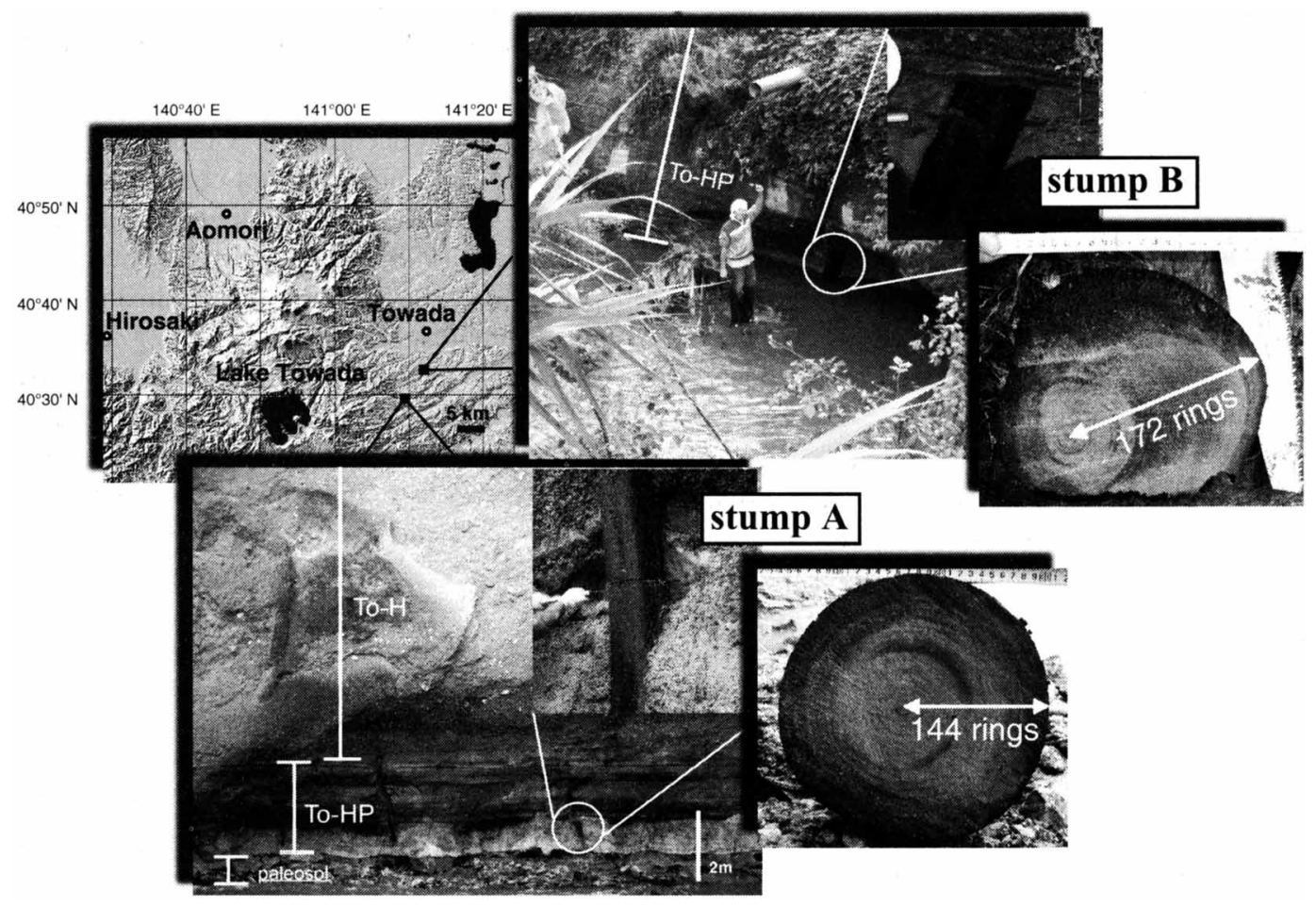

Figure 1 Locality and occurrence of the Towada Hachinohe buried forest, northeastern Honshu Island, Japan, and stumps A and B (A: $\left.40^{\circ} 29^{\prime} \mathrm{N}, 141^{\circ} 09^{\prime} \mathrm{E} ; \mathrm{B}: 40^{\circ} 32^{\prime} \mathrm{N}, 141^{\circ} 12^{\prime} \mathrm{E}\right)$. The Picea stumps were buried by a meters-thick pyroclastic fall deposit (ToHP) overlain by a $>10-\mathrm{m}$-thick pyroclastic flow (ToH). The stumps appear fresh, well preserved like a living tree. The total number of tree rings in A and B is 144 and 172, respectively. 
Microscope observations show both trees to be of the genus Picea, and burnt bark is retained on the wood. A dendrochronological investigation of the Towada Hachinohe buried forest (Terada et al. 1994) has revealed that almost all such erect Picea stumps with remaining bark were killed at the same time. This characteristic provides us with a unique situation in which we can cross-check the ${ }^{14} \mathrm{C}$ data of the last glacial period using the ages derived from the 2 stumps. It is also an important consideration that the appearance of the stump tree rings is fresh, resembling that of a living tree (Figure 1). Postdepositional alteration is likely to be minimal when compared to that ordinarily encountered in buried trees and plant remains.

\section{ANALYTICAL METHODS}

Both the A and B stumps were brought to the paleoenvironmental and cosmogenic nuclide laboratory of Hirosaki University, where they were dried on a clean bench for 4 weeks. A tree-ring count showed the total number of rings in A and B as 144 and 172, respectively. These rings are numbered inward, starting with \#1 assigned to the outermost ring. For this preliminary study, thin samples of well-preserved wood $(<1 \mathrm{~mm})$, each of which covered a 40-ring interval, were taken from the stumps using a razor. The typical weight of the samples was $0.1 \mathrm{~g}$. These were homogenized in an agate mill, and the outermost 5 rings of each stump were additionally subsampled. All samples were subjected to acid-alkali-acid (AAA) pretreatment.

Combustion of the samples, $\mathrm{CO}_{2}$ purification, and graphitization were performed in the AMS facility of the University of Tokyo (MALT; Matsuzaki et al. 2004). Duplicate graphite targets were produced for each $\mathrm{CO}_{2}$ gas sample (although a few graphite targets failed to produce sufficient mass during graphitization). ${ }^{14} \mathrm{C}$ analysis was performed by using the MALT AMS (Matsuzaki et al. 2004). The analytical precision was from $50-70 \mathrm{yr}$.

\section{RADIOCARBON AGES AND $\Delta^{14} \mathrm{C}$}

The results of the ${ }^{14} \mathrm{C}$ analysis are shown in Table 1 . The ${ }^{14} \mathrm{C}$ ages range between 13.0 and $13.3 \mathrm{kyr}$ BP. The ages of the same ring number agree well between stumps A and B, supporting the high reproducibility of our analysis, and there is no evidence in these internally consistent results that they were contaminated in situ with younger or older carbon. The ${ }^{14} \mathrm{C}$ ages of 13.0 and $13.3 \mathrm{kyr} \mathrm{BP}$ are within the range of the previous radiometric and AMS ${ }^{14} \mathrm{C}$ ages (about $12-14 \mathrm{kyr} \mathrm{BP}$ ) of the buried forest and volcanics, which concentrate around $13 \mathrm{kyr}$ BP (see Machida and Arai 2003). The ages correspond to $\sim 15.5 \mathrm{cal} \mathrm{kyr} \mathrm{BP}$ in the IntCal04 curve (Reimer et al. 2004), which is consistent with $\delta^{18} \mathrm{O}$-stratigraphic evidence from the marine sediment core LM-8 (Aoki and Arai 2000), suggesting the stratigraphic position of the ToH tephra to be around 15 cal kyr BP (Aoki and Arai 2000; Machida and Arai 2003).

Sakurai et al. (2004) and Gandou et al. (2004) have analyzed the ${ }^{14} \mathrm{C}$ of 2.5 -kyr BP and 22-kyr BP tree rings using the MALT AMS. They have confirmed that the ${ }^{14} \mathrm{C}$ ages of multiple graphite targets prepared from the same sample under the same conditions show a Gaussian distribution with a standard deviation equivalent to the average of the statistical (Poisson) error of each ${ }^{14} \mathrm{C}$ measurement. This suggests that the greater part of AMS precision is determined by the counting statistics, and they thus employed the weighted average ${ }^{14} \mathrm{C}$ ages of the multiple graphite targets to improve the ${ }^{14} \mathrm{C}$ age accuracy for each sample.

Because we have also used the MALT system, the same methodology can be applied to our results. The weighted averages of the ${ }^{14} \mathrm{C}$ ages for the same ring numbers of stumps $\mathrm{A}$ and $\mathrm{B}$ (Table 1) show excellent agreement within a small error value ( $40 \mathrm{yr})$. This again confirms the high reproducibility of our analysis and the remarkably good sample preservation. 
Table $1{ }^{14} \mathrm{C}$ data on 2 coniferous trees from the Towada Hachinohe buried forest.

\begin{tabular}{lclllll}
\hline Sample & Ring \# & Turn \# & Cathode \# & ${ }^{14}$ C age $(\mathrm{yr}$ BP) & Average (yr BP) & Lab\# \\
\hline A-1 & $1-5$ & 1 & 1 & $13,113 \pm 54$ & & MTC-03732 \\
& & & 2 & $13,161 \pm 58$ & $13,135 \pm 40$ & MTC-03733 \\
\hline B-1 & $1-5$ & 1 & 1 & $13,129 \pm 58$ & & MTC-03736 \\
& & 2 & 1 & $13,148 \pm 77$ & & MTC-04126 \\
& & & 2 & $13,154 \pm 84$ & $13,140 \pm 41$ & MTC-04127 \\
\hline A-2 & $1-40$ & 1 & 1 & $13,203 \pm 59$ & & MTC-03734 \\
& & & 2 & $13,172 \pm 60$ & $13,188 \pm 42$ & MTC-03735 \\
\hline B-2 & $1-40$ & 1 & 1 & $13,159 \pm 56$ & & MTC-03738 \\
& & & 2 & $13,127 \pm 56$ & & MTC-03739 \\
& & 2 & 1 & $13,227 \pm 64$ & & MTC-04128 \\
& & & 2 & $13,171 \pm 66$ & $13,167 \pm 30$ & MTC-04129 \\
\hline B-3 & $41-80$ & 1 & 1 & $13,039 \pm 63$ & & MTC-03740 \\
& & & 2 & $13,160 \pm 58$ & & MTC-03741 \\
& & 2 & 1 & $13,205 \pm 75$ & & MTC-04130 \\
& & & 2 & $13,272 \pm 77$ & $13,155 \pm 33$ & MTC-04131 \\
\hline A-4 & $81-120$ & 2 & 1 & $13,137 \pm 71$ & & MTC-04122 \\
& & & 2 & $12,976 \pm 70$ & $13,055 \pm 50$ & MTC-04123 \\
\hline B-4 & $81-120$ & 1 & 1 & $13,027 \pm 56$ & & MTC-03742 \\
& & & 2 & $13,005 \pm 55$ & & MTC-03743 \\
& & 2 & 1 & $13,147 \pm 71$ & $13,047 \pm 34$ & MTC-04133 \\
\hline A-5 & $121-140$ & 2 & 1 & $13,117 \pm 73$ & & MTC-04124 \\
& & & 2 & $13,140 \pm 67$ & $13,130 \pm 49$ & MTC-04125 \\
\hline B-5 & $121-160$ & 1 & 1 & $13,147 \pm 61$ & & MTC-03744 \\
& & 2 & 2 & $13,165 \pm 57$ & & MTC-03745 \\
& & 2 & $13,224 \pm 66$ & $13,176 \pm 35$ & MTC-04134 \\
\hline
\end{tabular}

Figure 2 shows the weighted averages of the ${ }^{14} \mathrm{C}$ ages plotted against the ring numbers. It is clear that the ${ }^{14} \mathrm{C}$ ages of the 2 stumps agree and also fluctuate concordantly throughout the total sample interval of about $150 \mathrm{yr}$. The fluctuation probably reflects a significant change in atmospheric ${ }^{14} \mathrm{C}$ concentration during this period, which may be discussed in the context of the $\Delta^{14} \mathrm{C}$ profiles.

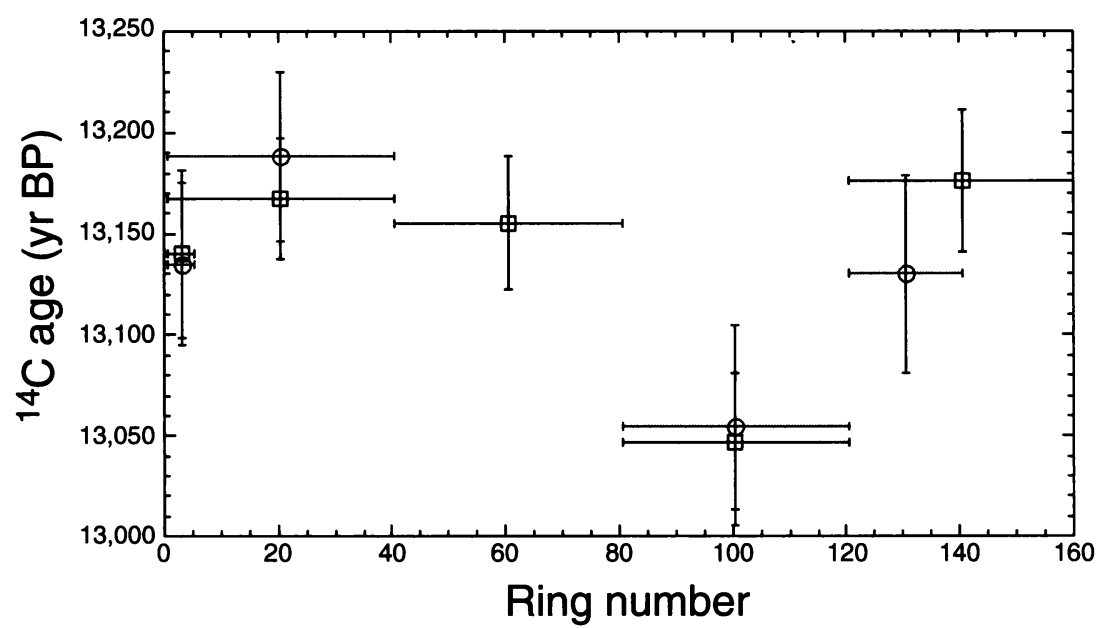

Figure 2 Weighted average ${ }^{14} \mathrm{C}$ ages plotted against ring number. The ${ }^{14} \mathrm{C}$ ages for each specimen agree and fluctuate concordantly throughout the total interval (circles: stump A; squares: stump B). 
Since we have had no independent chronology for stumps $\mathrm{A}$ and $\mathrm{B}$, a wiggle-matching technique is needed to obtain the $\Delta^{14} \mathrm{C}$ profiles. However, high-resolution ${ }^{14} \mathrm{C}$ profiles for $\sim 15.5 \mathrm{cal} \mathrm{kyr} \mathrm{BP}$, to serve as a target for the wiggle-matching, have not been published. Only a few varve and tree-ring data (Hughen et al. 2000, 2004b; Kromer et al. 2004) of decadal resolution reach 15 cal kyr BP. We therefore derived a calendar age for the outermost ring using the weighted average of all ${ }^{14} \mathrm{C}$ ages for the outermost 5 rings $\left(13,133 \pm 33{ }^{14} \mathrm{C} \mathrm{yr} \mathrm{BP}\right)$ and the IntCal04 curve. The age obtained was 15,512 cal BP, which is the mean of the $1-\sigma$ range (15,363-15,679 cal BP) using CALIB v 5.0.1 (Stuiver and Reimer 1993). Although this is tentative, the estimation of $\Delta^{14} \mathrm{C}$ values using this age supports our conclusions because only the extent of the fluctuation, not its values, is essential for the following discussion.

The estimated $\Delta^{14} \mathrm{C}$ values vary from 265 to $300 \%$ and show an approximately sinusoidal fluctuation of a presumably $\sim 200$-yr cycle (Figure 3). The possible causes of this fluctuation are changes in ocean circulation, geomagnetic field intensity, and solar activity. Ocean circulation variation could strongly influence atmospheric ${ }^{14} \mathrm{C}$ (e.g. Hughen et al. 2000), whereas periods of ${ }^{14} \mathrm{C}$ fluctuation resulting from geomagnetic field intensity are generally longer than century scale (e.g. Stuiver et al. 1991). Considering the nature of the fluctuation, we believe solar activity to be the most likely cause. A $30-40 \%$ change in $\Delta^{14} \mathrm{C}$ is comparable to the change attributed to solar activity with a $\sim 200$-yr cycle during the last millennium (Stuiver and Quay 1980; Reimer et al. 2004). Moreover, such $30-40 \%$ o century-scale fluctuations taking place after $15 \mathrm{cal} \mathrm{kyr}$ BP can be detected in the lastglacial ${ }^{14} \mathrm{C}$ tree-ring record (Kromer et al. 2004) and in the varved sediment of Suigetsu Lake (Kitagawa and van der Plicht 2000) and the Cariaco Basin (Hughen et al. 2004b). The scattered nature of these profiles, which might be partly owing to the precision of the ${ }^{14} \mathrm{C}$ measurement and/or counting age, would be smoothed by our $\sim 40$-yr sampling. This implies that the ${ }^{14} \mathrm{C}$ fluctuation around 15.5 cal kyr BP reflects a continuous $\sim 200$-yr cycle of past solar activity change. However, this interpretation is based on a few data of coarse resolution, and further analysis would be necessary to really determine if the cycle is present.

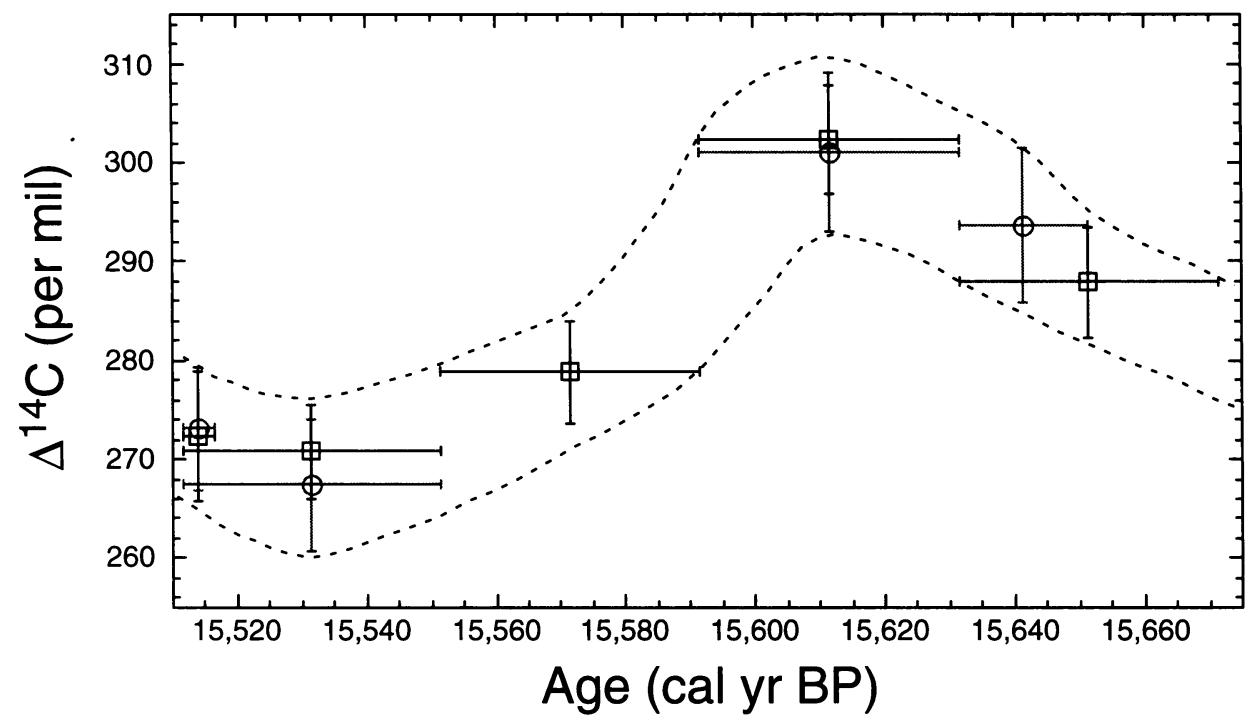

Figure 3 Estimated $\Delta^{14} \mathrm{C}$ profile for $\sim 15.5 \mathrm{cal} \mathrm{kyr}$ BP. The calendar age of the outermost rings of stumps $\mathrm{A}$ and $\mathrm{B}$ is assumed to be $15,512 \mathrm{cal} \mathrm{BP}$ (see text). The ${ }^{14} \mathrm{C}$ values show an approximately $30-40 \%$ amplitude sinusoidal curve and an indicated $\sim 200$-yr cycle, possibly reflecting contemporary solar activity changes. Dotted lines show the approximate range of the sinusoidal curve (circles: stump A; squares: stump B). 


\section{IMPLICATIONS FOR ${ }^{14} \mathrm{C}$ CALIBRATION CURVE AND POSSIBLE IMPACT OF THE ERUPTION}

Although we used the IntCal04 curve (Reimer et al. 2004) for our $\Delta^{14} \mathrm{C}$ estimation, it is unclear whether our results agree with certain ${ }^{14} \mathrm{C}$ records of this period or not. Figure 4 shows the weighted averages of the ${ }^{14} \mathrm{C}$ ages of stumps $\mathrm{A}$ and $\mathrm{B}$ plotted against calendar age in relation to the IntCal04 curve. Our data is mostly in the 1- $\sigma$ error range of IntCal04 and also close to the nearest calibration point presented by Bard et al. (1998). However, the detailed similarity and/or difference between our data and the atmospheric ${ }^{14} \mathrm{C}$ standard curve is unclear. That is partly because of the very coarse resolution of coral ${ }^{14} \mathrm{C}$ records used for constructing IntCal04 before $14.7 \mathrm{cal} \mathrm{kyr} \mathrm{BP}$; there are only 3 calibration points between 15 and $16.5 \mathrm{cal} \mathrm{kyr}$ BP. An alternative standard record other than the IntCal series may be the Cariaco Basin ${ }^{14} \mathrm{C}$ data (Hughen et al. 2004a). This record has higher time resolution during the target period than others such as the Lake Suigetsu ${ }^{14} \mathrm{C}$ record (Kitagawa and van der Plicht 1998, 2000). The Cariaco record is corrected with a marine reservoir age of $420 \mathrm{yr}$ for constructing an atmospheric ${ }^{14} \mathrm{C}$ curve, and is directly connected to the annual-layer chronology of the GISP2 ice core from Greenland (Meese et al. 1994, 1997).

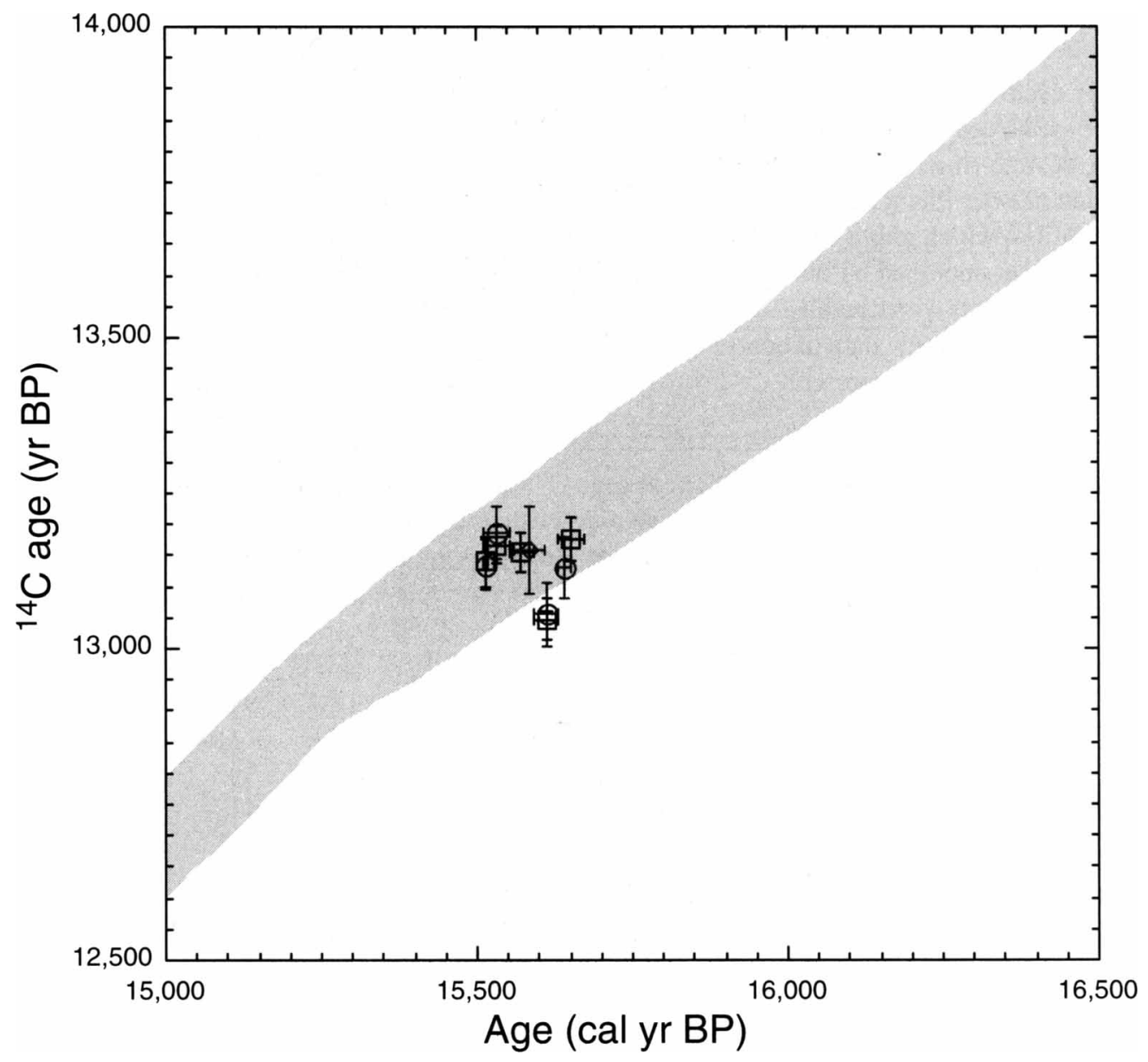

Figure 4 Comparison between our tree-ring data and the IntCal04 record (Reimer et al. 2004). The shaded area shows the $1-\sigma$ range of the IntCal04 curve. The age of the outermost ring is initially set to 15,512 cal BP (see text). The nearest calibration point provided by the Mururoa coral record (Bard et al. 1998) for IntCal04 is also shown here (diamond). Circles: stump A; squares: stump B. 
Figure 5a shows the Cariaco Basin record and our tree-ring data, in which the age of the outermost ring is set at the initial value of $15,512 \mathrm{cal} \mathrm{BP}$. Because of the large uncertainty of the calendar age of the Cariaco record due to multiplying the errors of both the correlation procedure and the GISP2 chronology, our data are clearly within the error range of the Cariaco record. On the other hand, using the raw Cariaco/GIPS2 age model without any errors on the calendar age estimation, we may have the following different "best match" between our tree-ring and the Cariaco records. The simplest solution is probably that shown in Figure 5b: the calendar age of the outermost ring is shifted about $+50 \mathrm{yr}$ from the initial value, and thus the age of the outermost ring becomes 15,560 GISP2 yr BP. In this case, we can follow the original 420-yr reservoir correction presented in Hughen et al. (2000) and there is only small discrepancy between the 2 profiles. Another somewhat drastic but better "best match" solution may be the case shown in Figure 5c: the calendar age of the outermost ring is shifted about $+680 \mathrm{yr}$ from the initial value, and thus the age of the outermost ring becomes 16,190 GISP2 yr BP. In this case, we have to use a 650-yr reservoir age for the Cariaco Basin record. Kromer et al. (2004) correlated their floating tree-ring ${ }^{14} \mathrm{C}$ data with the high-resolution, varve-chronology-based Cariaco ${ }^{14} \mathrm{C}$ record (Hughen et al. 2000, 2004b) of 12.8-14.2 cal kyr BP and showed that the best match appears in an estimation of a 650-yr reservoir age before the Younger Dryas period, instead of a 420-yr reservoir age since that time. If the latter case of our best match is correct, our data suggest that a 650-yr reservoir age of the Cariaco Basin is applicable at least from $16 \mathrm{cal} \mathrm{kyr}$ BP. Further high-resolution analyses of both our tree rings and the Cariaco Basin record are crucial for answering this interesting question and for precise dating of the Towada Hachinohe buried forest by using the wiggle-matching technique.

The eruption of ToH (and ToHP), which formed the Towada Hachinohe buried forest, is the largest volcanic event known of the last deglaciation stage (11.5-19 kyr BP) in Japan (Machida and Arai 2003). The Volcanic Explosivity Index (VEI) of this eruption is estimated at 6.7 (Hayakawa 1985). The precise chronology of this eruption is therefore quite important for studies of regional archaeology and Quaternary geology and perhaps for knowing the global impact of the huge eruption. Zielinski et al. (1996) showed the record of explosive volcanism from the GISP2 ice core using volcanic $\mathrm{SO}_{4}{ }^{2-}$ signals (EOF-5 values $>75 \mathrm{ppb}$ ) with the Meese et al. (1997) age model. From 15,400 to $16,400 \mathrm{GISP} 2 \mathrm{yr} \mathrm{BP}, 9$ signals are found in their $\mathrm{SO}_{4}{ }^{2-}$ profile. Around the horizons $( \pm 100 \mathrm{yr})$ corresponding to the estimated GISP2 ages of the outermost ring (15,560 and 16,190 BP), they extracted 4 peaks: a 103-ppb peak at 15,603 BP, a 111-ppb peak at 15,611 BP, a 75-ppb peak at 16,131 BP, and a 314-ppb peak at 16,191 BP. At present, we have no additional data for a detailed discussion on the origins of those signals. However, further ${ }^{14} \mathrm{C}$ analysis of tree rings from the Towada Hachinohe buried forest and comprehensive consideration of the atmospheric transportation and the preservation process of volcanic $\mathrm{SO}_{4}{ }^{2-}$ signals in ice cores would help to make clear the question of whether a ToH volcanic signal is really recorded in the Greenland ice core, as well as the global impact of this eruption.

\section{CONCLUSION}

The ${ }^{14} \mathrm{C}$ profiles for $\sim 15.5 \mathrm{cal}$ kyr BP obtained from the study of 2 fossil coniferous trees, both probably killed at the same time, show excellent agreement. This cross-check of ${ }^{14} \mathrm{C}$ data confirms the high reproducibility of our analysis and negligible postburial carbon contamination. The $\Delta^{14} \mathrm{C}$ values estimated by using an IntCal04 calibrated age $(15,512 \mathrm{cal} \mathrm{BP})$ of the outermost ring vary from 265 to $300 \%$ and illustrate an approximately sinusoidal curve of $30-40 \%$ amplitude and an indicated $\sim 200$-yr cycle. This ${ }^{14} \mathrm{C}$ fluctuation can be interpreted as reflecting past solar activity change. Comparison of the obtained ${ }^{14} \mathrm{C}$ profiles and the Cariaco Basin ${ }^{14} \mathrm{C}$ record suggests that the "best match" would be found in the case that the age of the outermost ring is 15,560 or $16,190 \mathrm{GISP} 2 \mathrm{yr}$ 

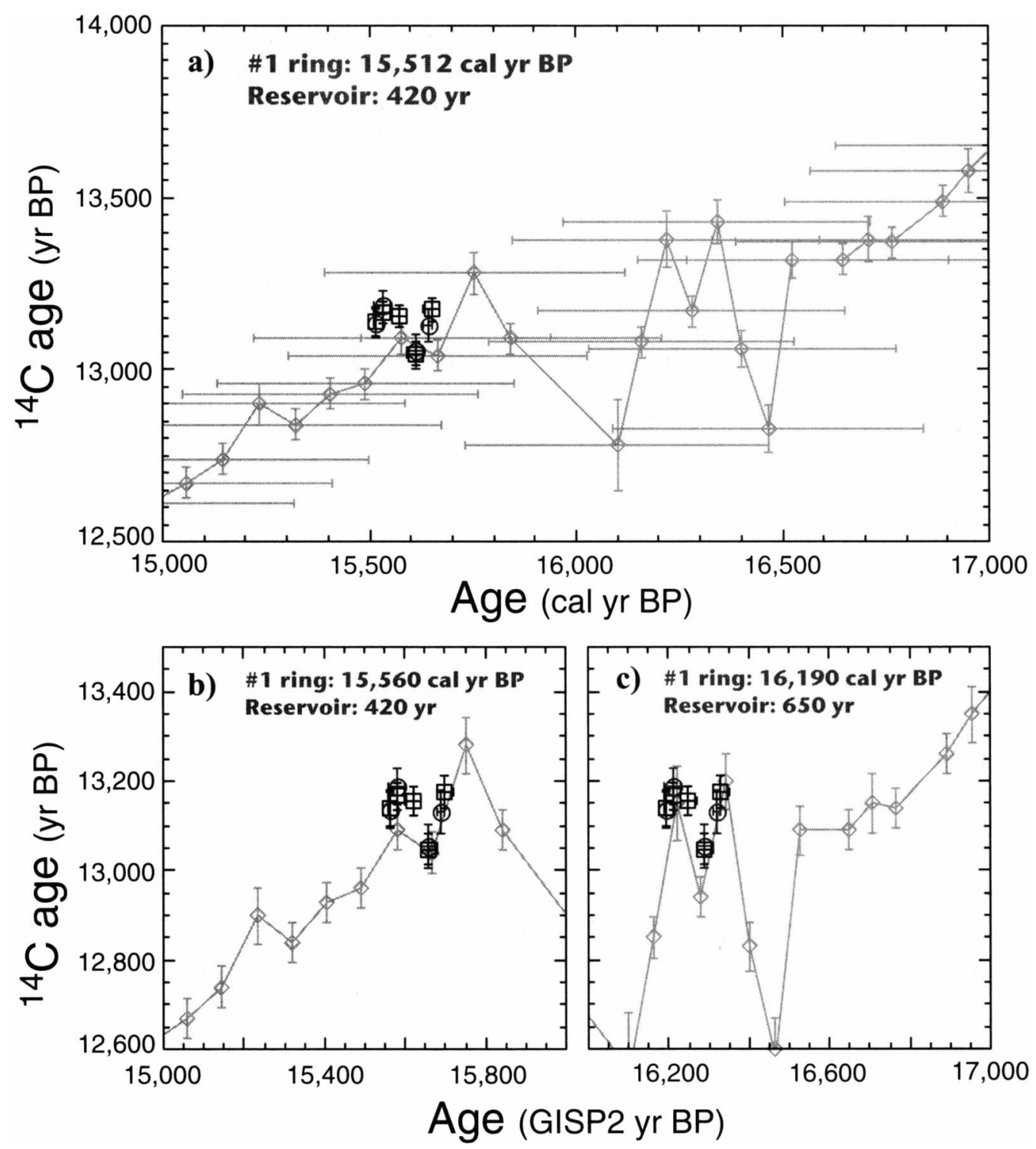

Figure 5 Comparison between our tree-ring data and the Cariaco Basin ${ }^{14} \mathrm{C}$ record (Hughen et al. 2004a): circles: stump A; squares: stump B; diamonds: Cariaco Basin. a) The calendar age of the outermost ring is set at 15,512 cal BP and the reservoir age of the Cariaco record is $420 \mathrm{yr}$ (the original value). The uncertainty of the calendar age of the Cariaco Basin record is estimated by multiplication of the errors of both the correlation procedure and GISP2 chronology (Hughen et al. 2004a). b) The age of the outermost ring is 15,560 cal BP and the reservoir age of the Cariaco record is $420 \mathrm{yr}$. c) The age of the outermost ring is $16,190 \mathrm{cal} \mathrm{BP}$ and the reservoir age of the Cariaco record is $650 \mathrm{yr}$. An estimated error of $\pm 180 \mathrm{yr}$ for the correlation procedure between Cariaco and GISP2 (Hughen et al. 2004a) is not shown in (b) and (c).

$\mathrm{BP}$; for the latter case, a 650-yr reservoir correction of the Cariaco Basin record is necessary. Such an attempt, with the help of ice-core records of volcanic signals and further ${ }^{14} \mathrm{C}$ analysis of the tree rings, would make clear the accurate age of the Towada Hachinohe buried forest and the global impact produced by the eruption. 
Although this study has obtained a reasonable ${ }^{14} \mathrm{C}$ profile, the analytical method may allow improvement. We are now investigating alternative pretreatment procedures such as Soxhlet extraction and/or delignification. This is an attempt to determine the single-year ${ }^{14} \mathrm{C}$ atmospheric concentration based on 2 coniferous tree samples from the last glacial period. Our work may help in the study of ice age solar activity using cosmogenic nuclides from both tree rings $\left({ }^{14} \mathrm{C}\right)$ and ice cores $\left({ }^{10} \mathrm{Be}\right.$ and $\left.{ }^{36} \mathrm{Cl}\right)$.

\section{ACKNOWLEDGMENTS}

We thank Ms E Hatakeyama, Mr H Murasawa, and Ms K Katsumi for their assistance in the sampling trip in August 2003. We also thank Mr T Gandou, Dr T Maejima, and Ms Y Sunohara for their support on the chemical experiments at the MALT. KH and MO thank Ms M Katsumata for her assistance in the tree-ring count. KH thanks Dr M Shiba, Mr N Nemoto, and Dr T Kudo, who provided the information on buried trees in Aomori Prefecture, Japan. We also thank 3 anonymous reviewers, whose comments significantly improved the manuscript. The geographic map shown in Figure 1 was produced by using the software Kashmir 3D (http://www.kashmir3d.com/). This work was supported in part by a Grant-in-Aid for Scientific Research (B) (No. 18340153) from the Japan Society for the Promotion of Science.

\section{REFERENCES}

Aoki K, Arai F. 2000. Late Quaternary tephrostratigraphy of marine core KH 94-3, LM-8 off Sanriku, Japan. Quaternary Research (Daiyonki Kenkyu) 39(2): 107-20. In Japanese with English abstract.

Bard E, Arnold M, Hamelin B, Tisnerat-Laborde N, Cabioch G. 1998. Radiocarbon calibration by means of mass spectrometric ${ }^{230} \mathrm{Th} /{ }^{234} \mathrm{U}$ and ${ }^{14} \mathrm{C}$ ages of corals: an updated database including samples from Barbados, Mururoa and Tahiti. Radiocarbon 40(3):108592.

Beck JW, Richards DA, Edwards RL, Silverman BW, Smart PL, Donahue DJ, Herrera-Osterheld S, Burr GS, Calsoyas L, Jull AJT, Biddulph D. 2001. Extremely large variations of atmospheric ${ }^{14} \mathrm{C}$ concentration during the last glacial period. Science 292(5526): 2453-8.

Broecker WS, Clark E, Hajdas I, Bonani G. 2004. Glacial ventilation rates for the deep Pacific Ocean. Paleoceanography 19: PA2002, doi:10.1029/ 2003 PA000974.

Bronk Ramsey C, Higham T, Leach P. 2004. Towards high-precision AMS: progress and limitations. Radiocarbon 46(1):17-24.

Fifield LK. 2000. Advances in accelerator mass spectrometry. Nuclear Instruments and Methods in Physics Research B 172(1-4):134-43.

Gandou T, Sakurai H, Katoh W, Takahashi Y, Gunji S, Tokanai F, Matsuzaki H. $2004 .{ }^{14} \mathrm{C}$ concentrations of single-year tree rings from about 22,000 years ago obtained using a highly accurate measuring method. $R a$ diocarbon 46(2):949-55.

Hayakawa Y. 1985. Pyroclastic geology of Towada Volcano. Bulletin of the Earthquake Research Institute University of Tokyo 60:507-92.
Hughen KA, Southon JR, Lehman SJ, Overpeck JT. 2000. Synchronous radiocarbon and climate shifts during the last deglaciation. Science 290(5498):19514.

Hughen K, Lehman S, Southon J, Overpeck J, Marchal O, Herring C, Turnbull J. 2004a. ${ }^{14} \mathrm{C}$ activity and global carbon cycle changes over the past 50,000 years. Science 303(5655):202-7.

Hughen KA, Southon JR, Bertrand CJH, Frantz B, Zermeño P. 2004b. Cariaco Basin calibration update: revisions to calendar and ${ }^{14} \mathrm{C}$ chronologies for core PL07-58PC. Radiocarbon 46(3):1161-87.

Kitagawa H, van der Plicht J. 1998. Atmospheric radiocarbon calibration to 45,000 yr B.P.: Late Glacial fluctuations and cosmogenic isotope production. Science 279(5354):1187-90.

Kitagawa H, van der Plicht J. 2000. Atmospheric radiocarbon calibration beyond 11,900 cal BP from Lake Suigetsu laminated sediments. Radiocarbon 42(3): 369-80.

Kromer B, Friedrich M, Hughen KA, Kaiser F, Remmele S, Schaub M, Talamo S. 2004. Late Glacial ${ }^{14} \mathrm{C}$ ages from a floating, 1382-ring pine chronology. Radiocarbon 46(3):1203-9.

Machida H, Arai F. 2003. Atlas of Tephra In and Around Japan [revised edition]. Tokyo: University of Tokyo Press. 336 p. In Japanese.

Matsuzaki H, Nakano C, Yamashita H, Maejima Y, Miyairi Y, Wakasa S, Horiuchi K. 2004. Current status and future direction of MALT, The University of Tokyo. Nuclear Instruments and Methods in Physics Research B 223-224:92-9.

Meese DA, Alley RB, Gow AJ, Grootes PM, Mayewski PA, Ram M, Taylor KC, Waddington IE, Zielinski 
GA. 1994. Preliminary depth-age scale of the GISP2 ice core. Special CRREL Report 94-1. Hanover, New Hampshire, USA: Cold Regions Research and Engineering Laboratory. $66 \mathrm{p}$.

Meese DA, Gow AJ, Alley RB, Zielinski, GA, Grootes PM, Ram M, Taylor KC, Mayewski PA, Bolzan JF. 1997. The Greenland Ice Sheet Project 2 depth-age scale: methods and results. Journal of Geophysical Research 102(C12):26,411-24.

Miyahara H, Masuda K, Muraki Y, Kitagawa H, Nakamura T. 2006. Variation of solar cyclicity during the Spoerer minimum. Journal of Geophysical Research 111: A03103, doi:10.1029/2005JA011016.

Noshiro S, Terada K, Tsuji S, Suzuki M. 1997. Larix-Picea forests of the Last Glacial Age on the eastern slope of Towada Volcano in northern Japan. Review of Palaeobotany and Palynology 98(3-4):207-22.

Oike S, Nakagawa H. 1979. Basic research for the regional agricultural development in Sannohe area. Tohoku Noseikyoku Keikakubu. p 1-103. In Japanese.

Reimer PJ, Baillie MGL, Bard E, Bayliss A, Beck JW, Bertrand CJH, Blackwell PG, Buck CE, Burr GS, Cutler KB, Damon PE, Edwards RL, Fairbanks RG, Friedrich M, Guilderson TP, Hogg AG, Hughen KA, Kromer B, McCormac G, Manning S, Bronk Ramsey C, Reimer RW, Remmele S, Southon JR, Stuiver M, Talamo S, Taylor FW, van der Plicht J, Weyhenmeyer CE. 2004. IntCal04 terrestrial radiocarbon age calibration, 0-26 cal kyr BP. Radiocarbon 46(3): 1029-58.

Robinson LF, Adkins JF, Keigwin LD, Southon J, Fernandez DP, Wang S-L, Scheirer DS. 2005. Radiocarbon variability in the western North Atlantic during the last deglaciation. Science 310(5753):1469-73.

Sakurai H, Gandou T, Kato W, Sawaki Y, Matsumoto T, Aoki T, Matsuzaki H, Gunji S, Tokanai F. 2004. AMS measurement of $\mathrm{C}-14$ concentration in a single-year ring of a 2500-yr-old tree. Nuclear Instruments and Methods in Physics Research B 223-224:371-5.

Solanki SK, Usoskin IG, Kromer B, Schüssler M, Beer J.
2004. Unusual activity of the Sun during recent decades compared to the previous 11,000 years. Nature 431(7012): 1084-7.

Stuiver M, Braziunas TF. 1998. Anthropogenic and solar components of hemispheric ${ }^{14} \mathrm{C}$. Geophysical Research Letters 25(3):329-32.

Stuiver M, Quay PD. 1980. Changes in atmospheric carbon-14 attributed to a variable Sun. Science 207(4426): 11-9.

Stuiver M, Reimer PJ. 1993. Extended ${ }^{14} \mathrm{C}$ data base and revised CALIB $3.0{ }^{14} \mathrm{C}$ age calibration program. $R a$ diocarbon 35(1):215-30.

Stuiver M, Kromer B, Becker B, Ferguson CW. 1986. Radiocarbon age calibration back to 13,300 years BP and the ${ }^{14} \mathrm{C}$ age matching of the German oak and US bristlecone pine chronologies. Radiocarbon 28(2B): 969-79.

Stuiver M, Braziunas TF, Becker B, Kromer B. 1991. Climatic, solar, oceanic and geomagnetic influences on late-glacial and Holocene atmospheric ${ }^{14} \mathrm{C} /{ }^{12} \mathrm{C}$ change. Quaternary Research 35(1):1-24.

Terada K, Ohta S, Suzuki M, Noshiro S, Tuji S. 1994. Dendrochronology of forests buried in Hachinohe tephra on the eastern slope of Towada Volcano, northern Japan. The Quaternary Research (Daiyonki Kenkyu) 33(3):153-64. In Japanese with English abstract.

van der Borg K, Stein M, de Jong AFM, Waldmann N, Goldstein SL. 2004. Near-zero $\Delta^{14} \mathrm{C}$ values at $32 \mathrm{kyr}$ cal BP observed in the high-resolution ${ }^{14} \mathrm{C}$ record from U-Th dated sediment of Lake Lisan. Radiocarbon 46(2):785-95.

Voelker AHL, Grootes PM, Nadeau M-J, Sarntheim M. 2000. Radiocarbon levels in the Iceland Sea from 25 $53 \mathrm{kyr}$ and their link to the Earth's magnetic field intensity. Radiocarbon 42(3):437-52.

Zielinski GA, Mayewski PA, Meeker LD, Whitlow S, Twickler MS. 1996. A 110,000-yr record of explosive volcanism from GISP2 (Greenland) ice core. Quaternary Research 45(2):109-18. 